\title{
PELATIHAN PEMBUATAN KOMPOS MENGGUNAKAN EFFECTIVE MICROORGANISMS (EM4) BAGI GURU-GURU SD NEGERI 18 PEKANBARU
}

\author{
Asyti Febliza*1, Zul Afdal ${ }^{2}$, Oktariani $^{3}$ \\ ${ }^{1,3}$ Fakultas Keguruan dan Ilmu Pendidikan, Universitas Islam Riau \\ ${ }^{2}$ Sekolah Tinggi Keguruan dan Ilmu Pendidikan Aisyiah Riau \\ Email: asytifebliza@edu.uir.ac.id
}

\begin{abstract}
Public Elementary School 18 Pekanbaru is one of autonomous adiwiyata school in 2012. The program done in this school is compost production. However, this act had not used effective microorganisms (EM4) so it caused more time consuming and ineffective for plants fertilizer. To overcome this problem, volunteer team conducted compost production training by using effective microorganisms (EM4) for teachers in Public Elementary School 18 Pekanbaru. The purpose of this activity is to increase teachers' knowledge about making compost by adding effective microorganisms (EM4). Demonstration and practice method was used in this activity. This program was conducted for two days in which the first day for delivering theory information and demonstration/practice about impulse sealer utilization. In the second day was conducted compost production training by using EM4. This activity located in Public Elementary School 18 Pekanbaru was conducted in several steps, namely: preparation step, implementation step, and evaluation step. Based on evaluation questionnaire result which was given to Public Elementary School 18 Pekanbaru teachers obtained information that approximately 72,7\% teachers' knowledge increased after training activity.
\end{abstract}

Keywords: Compost, Effective_microorganisms, teacher_training

\begin{abstract}
Abstrak
SD Negeri 18 Pekanbaru merupakan salah satu sekolah yang meraih penghargaan sebagai sekolah adiwiyata mandiri pada tahun 2012. Salah satu program yang dilaksanakan oleh SD Negeri 18 Pekanbaru yaitu pembuatan pupuk kompos. Namun, kegiatan pembuatan pupuk kompos yang dilakukan belum menggunakan EM4 sehingga proses pembuatan pupuk kompos yang dilakukan pihak sekolah menjadi lebih lama dan pupuk yang dihasilkan belum dapat memberikan hasil yang optimal bila diaplikasikan sebagai pupuk tanaman. Dalam menyelesaikan permasalahan ini, maka tim pengabdian mengadakan pelatihan pembuatan pupuk kompos menggunakan effective microorganisms (EM4) bagi guru-guru SD Negeri 18 Pekanbaru. Tujuan pelaksanaan kegiatan ini untuk meningkatkan pengetahuan guru-guru mengenai cara pembuatan pupuk kompos menggunakan effective microorganisms (EM4) melalui kegiatan pelatihan. Kegiatan pelatihan dilakukan dengan metode demonstrasi dan praktik. Kegiatan ini dilakukan selama 2 hari, dimana pada hari pertama dilaksanakan penyampaian materi secara teori dan demonstrasi/praktik mengenai teknik pengemasan menggunakan impulse sealer. Pada hari kedua dilaksanakan praktik pembuatan pupuk kompos menggunakan EM4. Kegiatan dilaksanakan di SD Negeri 18 Pekanbaru dengan beberapa tahapan kegiatan yaitu: tahap persiapan, tahap pelaksanaan dan tahap evaluasi. Hasil evaluasi yang diperoleh dari penyebaran angket kepada guru-guru sebelum dan sesudah kegiatan diperoleh bahwa pengetahuan guru-guru SD Negeri 18 Pekanbaru meningkat sekitar 72,7\% setelah kegiatan pelatihan.
\end{abstract}

Keywords: Kompos, Effective_microorganisms, teacher_training

PENDAHULUAN

Sekolah merupakan salah satu institusi Pendidikan yang dapat mendukung kegiatan penyelamatan bumi dan pengelolaan lingkungan. Menurut UndangUndang Nomor 32 Tahun 2009 tentang 
Perlindungan dan Pengelolaan Lingkungan Hidup dijelaskan bahwa "setiap orang berhak dan berperan dalam pengelolaan lingkungan hidup". Implementasi dari pernyataan tersebut di sekolah yaitu dilaksanakannya program sekolah adiwiyata. SD Negeri 18 Pekanbaru merupakan salah satu sekolah yang meraih penghargaan sebagai sekolah adiwiyata mandiri pada tahun 2012. Salah satu program yang dilaksanakan oleh SD Negeri 18 Pekanbaru yaitu pembuatan pupuk kompos. Namun, kegiatan pembuatan pupuk kompos yang dilakukan belum menggunakan EM4 sehingga proses pembuatan pupuk kompos yang dilakukan pihak sekolah menjadi lebih lama dan pupuk yang dihasilkan belum dapat memberikan hasil yang baik bila diaplikasikan sebagai pupuk tanaman. Dalam menyelesaikan permasalahan yang dialami mitra, maka tim pengabdian melaksanakan kegiatan pengabdian kepada masyarakat dengan mengadakan pelatihan pembuatan pupuk kompos menggunakan effective microorganisms (EM4) bagi guruguru SD Negeri 18 Pekanbaru.

Tujuan dari pelaksanaan pengabdian kepada masyarakat ini yaitu meningkatkan pengetahuan guru-guru mengenai cara pembuatan pupuk kompos dengan menggunakan effective microorganisms yang terdapat dalam cairan EM4 melalui kegiatan pelatihan.

EM4 merupakan bahan yang membantu mempercepat proses pembuatan pupuk organik dan meningkatkan kualitasnya. EM4 juga berperan dalam memperbaiki struktur dan tekstur tanah menjadi lebih baik serta menyuplai unsur hara yang dibutuhkan tanaman (Nur, Noor, \& Elma, 2016).

Pengomposan merupakan suatu metode untuk mengkonversikan bahan-bahan organik menjadi bahan yang lebih sederhana dengan menggunakan aktivitas mikroba. Proses pengomposan dapat berlangsung secara aerob dan anaerob. Pengomposan secara aerob merupakan proses dekomposisi bahan organik dengan memanfaatkan oksigen bebas yang ada (Kanwal, S., Iram, S., Khan, 2011), sedangkan pengomposan secara anerob terjadinya proses dekomposisi tanpa menggunakan oksigen bebas (Sarjono, S.E., Surya, E., dan Herlina, 2013). Aktivitas mikroba dipengaruhi oleh beberapa kondisi seperti: aerasi, media tumbuh dan sumber makanan (Yuwono, 2006).

\section{METODE PENGABDIAN}

Kegiatan pelatihan dilakukan dengan metode demonstrasi dan praktik. Kegiatan ini dilakukan selama 2 hari, dimana pada hari pertama dilaksanakan penyampaian materi secara teori dan demonstrasi/praktik mengenai teknik pengemasan menggunakan impulse sealer. Pada hari kedua dilaksankan praktik pembuatan pupuk kompos menggunakan EM4. Kegiatan dilaksanakan di SD Negeri 18 Pekanbaru dengan beberapa tahapan kegiatan yaitu: tahap persiapan, tahap pelaksanaan dan tahap evaluasi. Pada tahap persiapan dirancang modul pelatihan dan instrumen evaluasi untuk mengukur keberhasilan kegiatan pelatihan yang dilaksanakan. Selanjutnya, pada tahap pelaksanaan dilaksanakan kegiatan pelatihan yang dilaksanakan dengan dua kegiatan yaitu penyampaian teori,dan praktik pembuatan pupuk kompos oleh perwakilan guru. Dalam pelaksanaan kegiatan ini juga di praktikkan bagaimana Teknik pengemasan dengan menggunakan impulse sealer agar kompos dapat disimpan dengan baik setelah kompos matang. Sebelum kegiatan pelaksanaan dimulai, para peserta diberi angket sebelum kegiatan pelatihan untuk mengetahui sejauh mana pengetahuan peserta mengenai pelatihan yang diadakan. Setelah pelaksanaan pelatihan dilaksanakan kegiatan evaluasi mengenai kegiatan pelatihan yang telah dilaksanakan guna meninjau peningkatan pengetahuan peserta pelatihan setelah pelaksanaan kegiatan. Tahap evaluasi juga dilakukan untuk mengetahui keberhasilan dari pelaksanaan kegiatan pelatihan yang 
diberikan. Angket dianalisis secara kualitatif-kuantitatif, dimana penskoran dilakukan dengan menggunakan skala likert dan diinterpretasikan dalam bentuk persentase (Febliza, A., Afdal, 2015). Uraian kegiatan pada masing-masing tahapan dapat dilihat pada tabel 1 .

Tabel 1. Tahapan kegiatan pengabdian

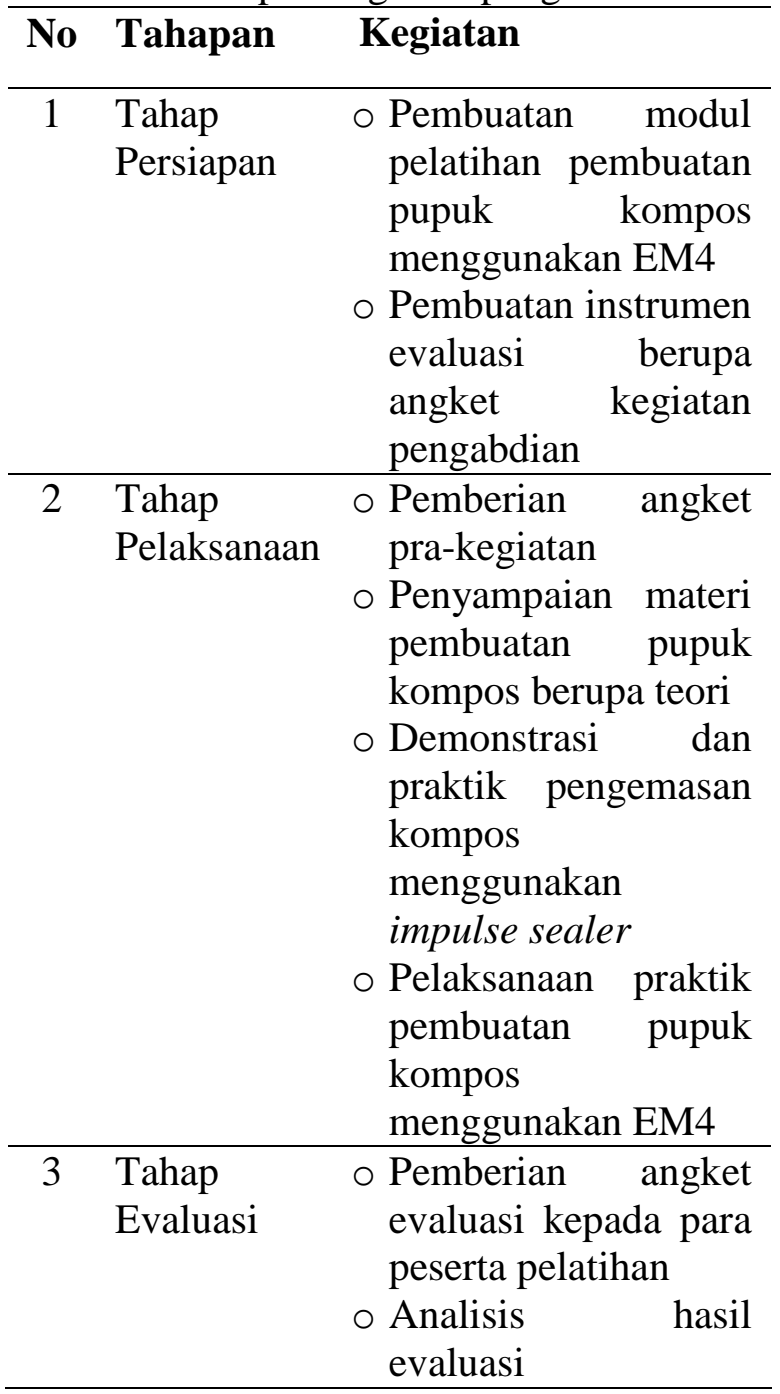

Adapun alat dan bahan yang digunakan dalam kegiatan pelatihan pembuatan pupuk kompos menggunakan EM4 yaitu: ember, cairan EM4 yang telah di fermentasi, sampah organik, dan impulse sealer.

\section{HASIL DAN PEMBAHASAN}

Kegiatan pelatihan dilaksanakan dengan beberapa kegiatan diantaranya: penyampaian materi berupa teori mengenai cara pembuatan pupuk kompos menggunakan EM4 cair dan Teknik pengemasan dengan impulse sealer. Adapun foto kegiatan penyampaian materi mengenai pupuk kompos dapat dilihat pada gambar 1 dan foto kegiatan demonstrasi Teknik pengemasan disajikan pada gambar 2.

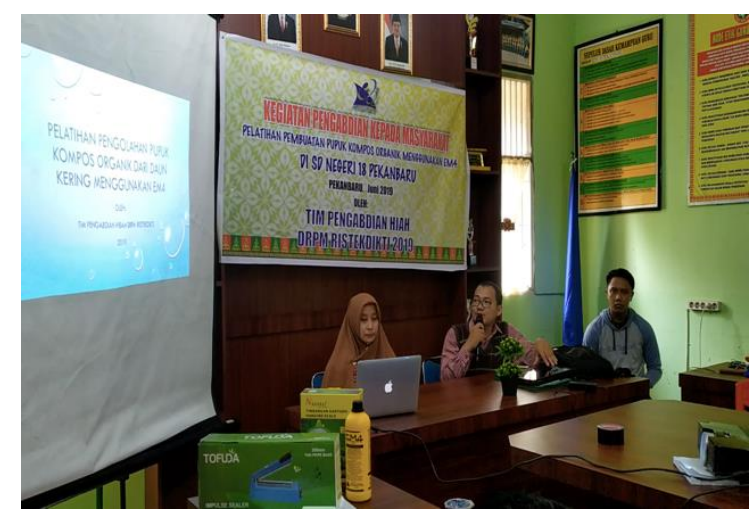

Gambar 1. Foto kegiatan penyampaian materi pupuk kompos

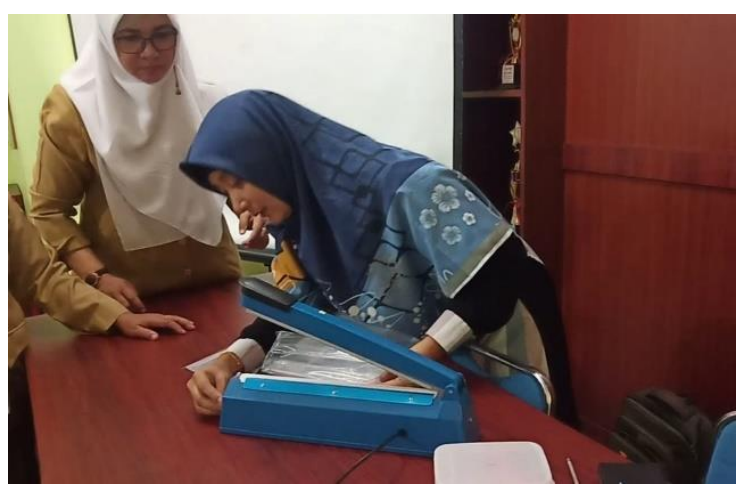

Gambar 2. Foto kegiatan demonstrasi

Teknik pengemasan

Selanjutnya, kegiatan dilanjutkan dengan demonstrasi dan praktik pembuatan pupuk kompos menggunakan EM4. Kegiatan diawali dengan pembuatan cairan sediaan EM4, dilanjutkan dengan kegiatan cara pengomposan dengan menggunakan cairan EM4 yang telah di fermentasikan. Kegiatan praktik dilakukan oleh perwakilan guru yang diadakan di lapangan tempat bak pengolahan kompos yang berada di belakang sekolah. Adapun foto kegiatan dapat dilihat pada gambar 3 . 


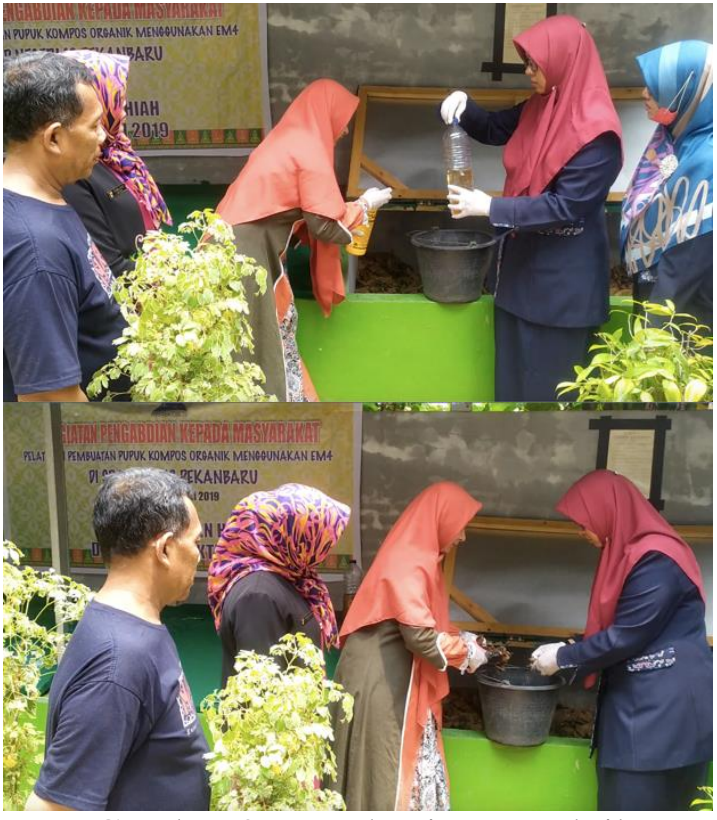

Gambar 3. Foto kegiatan praktik pembuatan pupuk kompos menggunakan EM4

Setelah kegiatan pelatihan dilaksanakan dilakukanlah evaluasi mengenai kegiatan pelatihan yang telah dilaksanakan. Hasil evaluasi yang diperoleh dari penyebaran angket kepada guru-guru sebelum dan sesudah kegiatan disajikan pada tabel 2 .

Tabel 2. Hasil penyebaran angket sebelum dan sesudah kegiatan pelatihan

\begin{tabular}{lcc}
\hline \multicolumn{1}{c}{ Pernyataan } & Sebelum & Sesudah \\
\hline $\begin{array}{l}\text { Sudah } \\
\text { mengetahui apa } \\
\text { itu EM4 }\end{array}$ & $9,1 \%$ & $90,9 \%$ \\
\hline $\begin{array}{l}\text { Sudah } \\
\text { mengetahui } \\
\text { fungsi EM4 }\end{array}$ & $9,1 \%$ & $90,9 \%$ \\
\hline $\begin{array}{l}\text { Sudah } \\
\text { mengetahui cara } \\
\text { menggunakan }\end{array}$ & $18,2 \%$ & $81,8 \%$ \\
$\begin{array}{l}\text { EM4 } \\
\text { Sudah bisa } \\
\text { menggunakan } \\
\text { impulse sealer } \\
\text { untuk } \\
\text { pengemasan }\end{array}$ & $9,1 \%$ & $72,8 \%$ \\
\hline
\end{tabular}

Berdasarkan tabel 2 dapat diketahui bahwa pengetahuan guru-guru mengenai pembuatan kompos menggunakan EM4 masih rendah dimana persentase pengetahuan peserta dibawah 18,2 \%, sedangkan pengetahuan peserta mengenai pengemasan dengan menggunakan impulse sealer hanya sevesar $9,1 \%$. Setelah kegiatan pelatihan dilaksanakan pengetahuan peserta meningkat 10 kali dari sebelumnya. Untuk melihat rata-rata peningkatan pengetahuan peserta secara keseluruhan disajikan pada gambar 4.

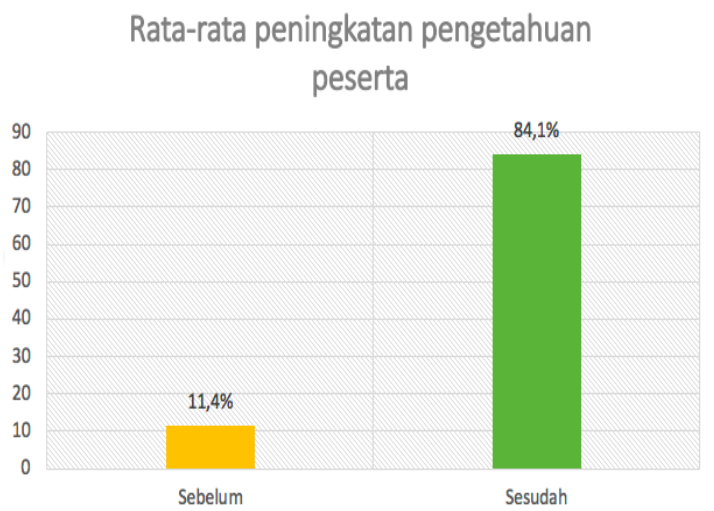

Gambar 4. Rata-rata peningkatan pengetahuan peserta sebelum dan sesudah pelatihan

Berdasarkan gambar 4 terlihat bahwa pengetahuan peserta pelatihan meningkat sekitar $72,7 \%$ setelah kegiatan pelatihan. Hal ini menggambarkan bahwa kegiatan pelatihan yang dilaksanakan dapat meningkatkan pengetahuan guru-guru SD Negeri 18 Pekanbaru.

\section{SIMPULAN}

Berdasarkan hasil dan pembahasan dapat disimpulkan bahwa kegiatan pelatihan pembuatan pupuk kompos menggunakan EM4 dapat meningkatkan pengetahuan guru-guru SD Negeri 18 Pekanbaru.

\section{UCAPAN TERIMA KASIH}

Terimakasih kepada

DRPM Kemenristekdikti yang telah memberikan dana dalam kegiatan pengabdian kepada masyarakat di SD Negeri 18 Pekanbaru.

\section{DAFTAR PUSTAKA}

[1] Nur, T., Noor, A. R., \& Elma, M. (2016). Tangga Dengan Penambahan 
$\overline{I S S N}: 2550-0198$

Bioaktivator EM 4 ( Effective Microorganisms ). Konversi, 5(2), 512.

[2] Kanwal, S., Iram, S., Khan, M. and A. (2011). Aerobic composting of water lettuce for preparation of phosphorus enriched organic manure. African Journal of Microbiology Research, 5(15), 1784-1793.

[3] Sarjono, S.E., Surya, E., dan Herlina, N. (2013). Pembuatan Pupuk Cair dan Biogas dari campuran Limbah Sayuran. Jurnal Teknik Kimia Universitas Sumatera Utara.

[4] Yuwono. (2006). Kecepatan Dekomposisi dan kualitas Kompos Sampah Organik. Jurnal Inovasi Pertanian, 4(2), 116-123.

[5] Febliza, A., Afdal, Z. (2015). Statistika Dasar Penelitian

Pendidikan. Pekanbaru: Adefa Grafika. 